Grammar School, the University of Melbourne, the University of Edinburgh, and the University of London, and is a doctor of science of the University of Melbourne. He was lecturer and reader in chemistry at University College, London, before and after the Great War, while in 1915-19 he was at the Research Department, Royal Arsenal, Woolwich. From 1921 until 1924 Prof. Masson was secretary of the Chemical Society, and he was a member of the Senate of the University of Durham in 1930-36. He is a member of the Council of the Institute of Chemistry and of the Council of the Universities' Bureau. He gave the Alexander Pedler Lecture of the British Science Guild in 1931, when he spoke on "Problems in the National Teaching of Science". His published work includes "Three Centuries of Chemistry" (1925), papers on physical, inorganic and organic chemistry in the journals of the Royal Society, Chemical Society, etc., and occasional bibliographical studies in the Transactions of the Bibliographical Society.

\section{Earthquake of June II}

AT 11.58 a.m. (G.M.T.) on June 11, an earthquake of unusual severity was felt all over Belgium and Holland, in the south-west of Germany, the north-east of France and the south-east of England. From the early accounts, the intensity of the shock seems to have been greatest in the west of Belgium, where buildings were slightly damaged, several persons were injured and one was killed. In France, it was most severe in the district around Lille, where many chimneys were thrown down, and at Roubaix, close to the Belgian frontier, where about twenty persons were injured. It was felt also at Boulogne and Paris and, it is said, at Strasbourg. It was observed all over Hollend, though but slightly in the north and east of that country. In the south-east of England, especially in Kent, the earthquake was felt rather strongly and also at places so far from the origin as London, Ipswich and Brighton. The disturbed area must therefore have been at least 380 miles long from east to west and $\mathbf{3 3 0}$ miles wide, and have contained not less than 100,000 square miles. It is difficult at present to assign the position of the epicentre. It may have been under the North Sea near the coast of Belgium, or on land in the west of that country. The earthquake was clearly of less intensity than that of April 6, 1580, but, though many of the places disturbed by both shocks are the same, its epicentre must have lain some distance to the east of that of the earlier earthquake, which, as Mr. E. R. Ockenden has shown (NATURE, 138, 472 ; 1936) was probably submarine and near the east coast of Kent.

\section{Commemorative Window at the Old Ashmolean, Oxford}

ON June 11, in the Museum of the History of Science, Oxford, the new window commemorating the gifts of the Mercers', Grocers' and Merchant Taylors' Companies, the Royal College of Physicians and of the Friends of the Old Ashmolean, was unveiled by the Vice-Chancellor in presence of a large and representative audience. Before the unveiling, speeches were made in the Divinity School by Sir Cecil Clementi, Sir Henry Norbury, Dr. $\mathbf{R}$. Hutchison and Dr. G. D. Parkes and also by the Vice-Chancellor. The new window is placed at the bottom of the staircase of the Museum next to a similar window unveiled by Lord Birkenhead about nine years ago. At the top is represented the arms of Dr. R. T. Gunther, the present keeper and virtual founder of the Museum as it has now become. Below this are represented the arms and crests of the City Companies mentioned and the arms of the Royal College of Physicians.

\section{Meyerstein Institute of Radio-Therapy}

THE Meyerstein Institute of Radio-Therapy at the Middlesex Hospital, London, was opened by Sir William Bragg on June 9, before a large audience with many representatives of medicine and science. Sir William Bragg referred in reminiscent terms to the early days of $\mathrm{X}$-rays and radioactivity, pointing out the ever-growing interest in the quest of the invisible phenomena about us. The Institute which he declared open is at the north end of the original Cancer Wing of the Hospital, four floors of which have been reconstructed and adapted to radiological work. The main equipment consists of four X-ray installations having Metropolitan-Vickers tubes actuated at 250 kilovolts, four Newton and Wright sets of oil-cooled Siemens tubes to be run at 200 kilovolts, and a 4-gram radium unit, the radium being automatically transferred to a large radium safe surrounded by 10 inches of lead when not in actual use upon patients. The protection of the personnel has been carefully studied throughout the entire working arrangements. The layout of the Institute is of a very pleasing as well as efficient character, being well ventilated and lighted, with ample space and air for patient and operator alike. The whole policy has been to provide trustworthy apparatus with the best possible conditions under which a selected staff can pursue radiological investigation.

\section{East Malling Research Station}

ThE purchase by East Malling Research Station of the adjoining property of Bradbourne will provide a background of more than ordinary interest for the future activities of the Station. Originally a moated Tudor house built around an open courtyard, Bradbourne was transformed in the early eighteenth century into a typical Queen Anne mansion. From the Station's point of view, the estate of 200 acres is an even more important acquisition than the house itself, providing opportunity for future development of field experiments under conditions which are typical of much of the fruit-growing land in Kent. The open ground in the district has already been largely built over, and had Bradbourne been allowed to suffer a similar fate, the expansion of research activities of the Station in future years might have been seriously hampered. The prompt action taken by the committee in securing the estate when it came into the market has met with encouragement and support from the Government and from several important public bodies including the National Trust, the Council for the Preservation of Rural England, 
the Pilgrim Trust, and the Society for the Protection of Ancient Buildings. An enterprise of this nature which will mean at one and the same time the safeguarding of land for the development of scientific research and the preservation of a green belt in an area rapidly becoming industrialized, should have a double appeal : to those who think well of East Malling as a research centre, and to those also who approve of keeping part at least of the 'Garden of England' unspoilt. Such a project as the purchase and maintenance of Bradbourne must necessarily entail a heavy strain on the Station, and it may be several years before it is free from financial anxiety. Hence any contributions towards paying off the debt for the purchase and restoration will be welcomed by the Director, East Malling Research Station, Near Maidstone, Kent.

\section{B.M.A. Committee on Mental Health}

THE ever-recurring problems of sickness both in industry and in the general population which cannot be satisfactorily diagnosed or relieved by reference to the bodily symptoms alone, has led to a slowly developing interest into the mental aspect of disease. More than ten years ago, a report of the Industrial Health Research Board gave experimental evidence that led to the view that telegraphists' cramp was a psycho-neurotic manifestation. Studies of industrial sickness-absence show that much inefficiency, lost time and unhappiness are related to disorders of the type vaguely labelled nervous breakdown. Also investigations into industrial failures show that a large proportion are people whose disabilities are of a mental or emotional nature. It is therefore opportune that a special committee of the British Medical Association should be appointed to study the problem of mental health in general. The committee is to make a thorough study of all the available statistics and will seek to compare the importance of mental illness with other conditions already recognized by the State as requiring action. It will consider the part which the general practitioner, hospitals, clinics under the Mental Treatment Act, child guidance and other clinies, can play in the prevention of such iliness, and study the degree of success attainable by the present available methods of treatment. A very important part of the committee's work will be to consider the part allotted to psychological medicine in medical training. The members of the committee are as follows : Sir Robert Johnston (president), Sir Kaye le Fleming (chairman of council), Mr. H. Guy Dain (chairman of representative body), Mr. N. Bishop Harman (treasurer), Sir Henry Brackenbury. Dr. J. A. Brown, Dr. Millais Culpin, Dr. R. G. Gordon, Sir Walter Langdon-Brown, Dr. Mary C. Luff, Dr. E. Mapother, Dr. Doris M. Odlum, Dr. A. A. W. Petrie, Dr. J. R. Rees, Dr. Benjamin Reid, Dr. D. Stewart, and Dr. R. M. Stewart.

\section{Bureau of Human Heredity}

AN appeal for funds on behalf of the Bureau of Human Heredity, which appears in The Times of June 7, gives some slight indication of the value of the work which has been carried out by this organiza. tion with the limited resources at its disposal and in the brief period since its foundation. The function of the Bureau is to centralize in one organization as a world clearing-house the information already accurately ascertained on the inborn constitutional factors in man, and to distribute it freely wherever it is required. In less than eighteen months the Bureau has accumulated data on the inheritance of more than six hundred physical and mental differences. As a result of a financial appeal in May 1936 , the Bureau secured sufficient support to enable it to carry on from day to day, while a grant for one year was made by a scientific worker. The present appeal is headed by Lord Dawson of Penn, with the support of Sir F. Gowland Hopkins, Sir E. Farquhar Buzzard, Sir Richard Gregory and others. In their view, the facts warrant an appeal to the public for a sum of $£ 25,000$, an amount which is not considered excessive in view of the importance of the work to be carried on. It would enable the activities of the Bureau to be placed on a permanent basis. In justification, the signatories to the appeal point out that attempts to improve the lot of the individual must remain largely ineffective so long as the data which reveal his inborn nature remain obscure. When the Bureau has been placed in a position to carry out its functions normally in accordance with the intentions of its promoters, it will be possible for any medical man to obtain in English the latest information from any country relating to, for example, the resistance or non-resistance of certain types to common infections, or occupational disease. Research workers themselves are well aware that the organiza. tion of knowledge, such as that upon which the Bureau is engaged, is little less important for scientific progress than research itself. Without it there is risk that much valuable work may suffer oblivion. The appeal is issued from the Bureau of Human Heredity, 115 Gower Street, London, W.C.1.

\section{Haslemere Educational Museum}

ThE Haslemere Educational Museum will celebrate, on June 29, the fiftieth anniversary of its foundation. The speakers on the occasion will be Earl Winterton and Dr. John Ramsbottom. This museum was founded in $\mathbf{1 8 8 8}$ by Sir Jonathan Hutchinson, F.R.S., at a time when the majority of the smaller museums were stagnant and uninspiring because they lacked teachers. Hutchinson was a great teacher, and through. his teaching the museum at his country house at Inval, about a mile from Haslemere, quickly made its influence felt. There he arranged for the first time the space-for time schedules of geology and human history which are still a special feature of the museum, and these schedules were largely used in his lectures to friends and to members of the Haslemere Natural History Society. In less than ten years the Museum had completely outgrown itself, and Hutchinson then built a much more commodious one in Haslemere on the hillside to the south-east of the town, and there continued to lecture at weekends in the summer months. 